\title{
Genetic variants associated with fasting blood lipids in the U.S. population: Third National Health and Nutrition Examination Survey
}

\author{
Man-huei Chang ${ }^{* 1}$, Ajay Yesupriya' ${ }^{1}$, Renée M Ned ${ }^{1}$, Patricia W Mueller² and Nicole F Dowling ${ }^{1}$
}

\begin{abstract}
Background: The identification of genetic variants related to blood lipid levels within a large, population-based and nationally representative study might lead to a better understanding of the genetic contribution to serum lipid levels in the major race/ethnic groups in the U.S. population.

Methods: Using data from the second phase (1991-1994) of the Third National Health and Nutrition Examination Survey (NHANES III), we examined associations between 22 polymorphisms in 13 candidate genes and four serum lipids: high-density lipoprotein cholesterol (HDL-C), low-density lipoprotein cholesterol (LDL-C), total cholesterol (TC), and triglycerides (TG). Univariate and multivariable linear regression and within-gene haplotype trend regression were used to test for genetic associations assuming an additive mode of inheritance for each of the three major race/ethnic groups in the United States (non-Hispanic white, non-Hispanic black, and Mexican American).

Results: Variants within APOE (rs7412, rs429358), PON1 (rs854560), ITGB3 (rs5918), and NOS3 (rs2070744) were found to be associated with one or more blood lipids in at least one race/ethnic group in crude and adjusted analyses. In nonHispanic whites, no individual polymorphisms were associated with any lipid trait. However, the PON1 A-G haplotype was significantly associated with LDL-C and TC. In non-Hispanic blacks, APOE variant rs 7412 and haplotype T-T were strongly associated with LDL-C and TC; whereas, rs5918 of ITGB3 was significantly associated with TG. Several variants and haplotypes of three genes were significantly related to lipids in Mexican Americans: PON1 in relation to HDL-C; APOE and NOS3 in relation to LDL-C; and APOE in relation to TC.

Conclusions: We report the significant associations of blood lipids with variants and haplotypes in APOE, ITGB3, NOS3, and PON1 in the three main race/ethnic groups in the U.S. population using a large, nationally representative and population-based sample survey. Results from our study contribute to a growing body of literature identifying key determinants of plasma lipoprotein concentrations and could provide insight into the biological mechanisms underlying serum lipid and cholesterol concentrations.
\end{abstract}

\section{Background}

Decades of research have demonstrated that serum concentrations of blood lipids are associated with increased risk for cardiovascular disease and mortality [1-4]. Previous reports from the Framingham Heart Study suggested a strong positive relationship between coronary heart disease and elevated levels of total cholesterol (TC) and lowdensity lipoprotein cholesterol (LDL-C) levels, in addition to an inverse relationship between the disease and

* Correspondence: mchang@cdc.gov

${ }^{1}$ National Office of Public Health Genomics, Centers for Disease Control and Prevention, Atlanta, GA, USA

Full list of author information is available at the end of the article high-density lipoprotein cholesterol (HDL-C) levels [5-8]. The genetic basis for elevation in lipid levels is not well understood, but substantial heritability has been demonstrated in twin [9] and family-based [10-12] studies, which have estimated that approximately $43 \%$ to $83 \%$ of the variance in blood lipid and lipoprotein levels is attributable to genetic factors. Recent candidate gene studies [13-16], as well as genome-wide association studies [1725], have identified polymorphisms that account for a portion of the variation in blood lipid levels.

Many genes involved in metabolic pathways have been found to contribute to lipid level variability $[14,26,27]$. 
However, conflicting findings are common among genetic association studies. Inconsistencies might be caused by differences in study design, study populations (geographic and ethnic background), statistical methods and power, allele frequencies, and gene-environment interactions. It is not clear if such findings are generalizable to the U.S. population. To assess genetic variation among racial and ethnic groups in the U.S. population, we need genetic information from a large, well-designed, and population-based U.S. survey, such as the Third National Health and Nutrition Examination Survey (NHANES III) that includes the three major race/ethnic groups. Therefore, we sought to investigate the associations between 22 polymorphisms in 13 candidate genes and serum lipid concentrations using data from the NHANES III, a nationally-representative survey of the U.S. population.

\section{Methods}

\section{Study population}

NHANES III is a multi-stage complex probability survey conducted from 1988 to 1994 by the National Center for Health Statistics (NCHS) of the Centers for Disease Control and Prevention (CDC) [28,29]. The survey was designed to provide nationally representative statistics on the civilian, non-institutionalized U.S. population aged 2 months or older. A DNA bank was created from blood samples collected during the second phase of NHANES III (1991-1994) from participants aged 12 years or older. This DNA bank provided one of the first opportunities to assess genetic variation among major racial and ethnic groups using a well-designed, population-based, and nationally representative sample of the U.S. population. The bank contains specimens from 7,159 participants, $62 \%$ of whom originated from households containing multiple family members (mean: 1.59 participating members per household; range 1-11). More information on the DNA bank is available on the NCHS Web site [30].

We combined genetic data with behavioral, environmental, and clinical information available in NHANES III. We restricted our analyses to participants aged 17 years or older $(n=6,317)$. Of these, we included only those who self reported as non-Hispanic white, non-Hispanic black, or Mexican American $(n=6,016)$, who had their blood drawn in the morning $(\mathrm{n}=2,712)$, who fasted at least 9 hours $(n=2,488)$, and who did not take cholesterol-lowering medications $(\mathrm{n}=2,413)$. This study was approved by the NCHS Ethics Review Board.

\section{Selection of polymorphisms}

We tested 22 polymorphisms in 13 candidate genes that were chosen from a set of variants that we previously genotyped in the NHANES III DNA Bank [31], including polymorphisms in $A B C B 1, A D H 1 C, A D R B 2, A D R B 3$, APOE, ITGB3, MTHFR, MTRR, NOS3, SERPINE1,
PON1, PPARG, and TNF (Additional file 1, Table S1). The candidate genes included in this current study were identified from systematic literature reviews on previously published associations with blood lipid levels, chosen based on the biology of the disease locus in relation to the outcomes, or chosen based on prior linkage studies. Information on the nucleotide or amino acid change for each variant is included in Additional file 1, Table S1.

\section{Genotyping methods}

All genotypes were analyzed using TaqMan (Applied Biosystems, Foster City, California) or MGB Eclipse (Nanogen, Bothell, Washington) assays. Polymorphisms that passed blind-replicate analyses $(\geq 98 \%$ of genotypes matched) were tested for deviation from Hardy-Weinberg proportions (HWP) using standard chi-square goodness-of-fit tests. Variants that deviated from HWP at $p<0.01$ for at least two of the three included race/ethnic groups (i.e., non-Hispanic white, non-Hispanic black, and Mexican American) were excluded from further analysis. Detailed genotyping methods and quality control criteria have been previously described [31] or can be obtained from NCHS (in the case of $A P O E$ ).

\section{Laboratory measures and phenotype definitions}

Details of the blood collection procedures and the laboratory evaluation of LDL-C, HDL-C, TC, and TG are available online [32]. Serum LDL-C was calculated using the Friedewald equation [33]. Participants who did not fast, who fasted fewer than 9 hours, or who had TG levels greater than $400 \mathrm{mg} / \mathrm{dL}$ were excluded in the analyses.

Phenotypic covariates included in the analyses were previously reported to be associated with blood lipid levels [34]. In non-genetic models, age and body mass index (BMI) were both strongly associated with blood lipid concentrations within each race/ethnic group (Additional file 1, Table S2). The remaining risk factors were significantly associated with at least one lipid measured in at least one race/ethnic group. The covariates included in the final models were: age (17-39 years, $40-59$ years, or $\geq 60$ years); sex; education completed (less than high school, high school, or college and above); alcohol intake (none, $<4$ drinks per week, $\geq 4$ drinks per week); smoking status (current smoker, former smoker, non-smoker); BMI; physical activity [none, low (active $<5$ times per week), or high (active $\geq 5$ times per week)]; and log of total fat intake (g/day, reported in a dietary recall from the previous 24-hour period).

\section{Statistical analysis}

All analyses were performed using SAS-Callable SUDAAN 9.01 (Research Triangle Institute, Research Triangle Park, North Carolina) and SAS 9.1 (SAS Institute, Cary, North Carolina) to account for the NHANES III complex sampling design. For each genetic variant, 
univariate and multivariable regression models were used to test for genetic associations with each blood lipid measurement, stratified by self-reported race/ethnicity. Interaction between each variant and race/ethnicity was examined to test racial/ethnic differences in the genetic effects. We assumed an additive model of inheritance and used regression analyses to test the null hypothesis that LDL-C, HDL-C, TC, or TG levels did not differ by an increasing number of minor alleles. Beta-coefficient estimates and $95 \%$ confidence intervals for each variant were calculated in regression models using sample weights that were recalculated for the NHANES III DNA bank data. TG levels were log-transformed to approximate a normal distribution.

Haplotype analysis was also performed for each of the seven genes for which at least two polymorphisms were genotyped: $A D H 1 C, A D R B 2, A P O E, M T H F R$, NOS3, $P O N 1$, and TNF. Haplotype frequencies were inferred within each racial/ethnic group using the ExpectationMaximization algorithm $[35,36]$ available in the HAPLOTYPE procedure in SAS/Genetics. The inferred haplotypes with rare frequency $(<1 \%)$ were combined into one variable ("other"). Haplotype trend regression analyses $[37,38]$ were conducted using crude and multivariable regression models, as described above.

For both the single variant analyses and haplotype analyses, the p-value from Satterthwaite statistics was adjusted to control the false discovery rate (FDR) [39], a method for correcting for multiple testing, in each of the three race/ethnic groups separately. An association was considered significant at an FDR-adjusted p-value of < 0.05 .

We used Quanto (University of Southern California, Los Angeles, California; http://hydra.usc.edu/gxe/) to estimate the power of our study. Assuming additive genetic models, we determined the beta-coefficients that correspond to a genetic variant explaining $1 \%$ of the variation in the lipid measurements for allele frequencies ranging from 0.01 to 0.5 . For these beta-coefficients and allele frequencies, we calculated the lower and upper limits of our power which account for our multiple testing adjustments using the effective sample sizes (sample sizes multiplied by a design effect of 1.2 to account for the complex sampling design of NHANES III) of the three race/ethnicities.

\section{Results}

Characteristics of the participants included in this study are described in Table 1. Non-Hispanic whites $(\mathrm{n}=989)$ were the oldest, had obtained higher levels of education, and were the most physically active compared to nonHispanic blacks and Mexican Americans. Non-Hispanic blacks $(n=683)$ were least likely to have consumed any alcoholic drinks in the past week, were most likely to be current smokers, and had the highest mean body mass index (BMI). Mexican Americans $(\mathrm{n}=741)$ were the youngest, had the highest proportion of male participants, and were the least likely to smoke. Blood lipid levels were also significantly different (at $p<0.05)$ across the three main race/ethnic groups. Non-Hispanic blacks tended to have the highest HDL-C levels compared with non-Hispanic whites and Mexican Americans. In contrast, non-Hispanic whites had the highest LDL-C and TC levels; whereas, Mexican Americans had the highest serum triglycerides levels.

Allele frequencies for the study variants among the three racial/ethnic groups in the U.S. population are available in Additional file 1, Table S1. Each genetic variant was tested for association with each of the four blood lipid measurements. Table 2 lists the genetic variants with significant associations ((false-discovery rate (FDR)adjusted $\mathrm{p}$-value $<0.05)$ ) in at least one race/ethnic group for the crude or adjusted regression models. Complete results for all studied variants, with and without FDR adjustment of p-values, are available in Additional file 1, Table S3a-d (crude analyses) and Table S4a-d (covariateadjusted analyses). The FDR-adjusted and unadjusted pvalues for testing racial/ethnic differences in the genetic effects (SNP $\times$ race/ethnicity interaction) are also included in these Additional Tables. In fasting samples from non-Hispanic whites, none of the studied variants were found to be significantly associated with any blood lipids after adjustment for multiple testing. For non-Hispanic blacks, $A P O E$ rs7412 was strongly associated with both LDL-C and TC in crude and adjusted analyses. We observed that several polymorphisms were significantly associated with blood lipids in the Mexican American population, including: PON1 rs854560 with HDL-C in both crude and adjusted analyses; $A P O E$ rs7412 and rs429358 with LDL-C and TC in adjusted analyses; and NOS3 rs1799983 with LDL-C in adjusted models only. None of the 22 polymorphisms were found to be associated with triglyceride levels except for ITGB3 rs5918 in non-Hispanic blacks.

Haplotypes with significant associations with blood lipids in at least one race/ethnic group in crude or adjusted models are listed in Table 3. Complete results are included in Additional file 1, Tables S5a-d (crude analyses) and S6a-d (covariate-adjusted analyses). In the three race/ethnic groups, all polymorphisms within a gene were in linkage disequilibrium $(p<0.05$ from linkage disequilibrium test; data not shown). Consistent with the results of the individual polymorphisms, haplotypes within three genes (APOE, NOS3, and PON1) were found to be significantly associated (FDR-adjusted $\mathrm{p}<0.05$ ) with blood lipid levels. In non-Hispanic whites, the only significant associations found were for the A-G haplotype of PON1 in relation to elevated LDL-C in crude and 
Table 1: Characteristics of study fasting samples - NHANES III (1991-1994)

\begin{tabular}{|c|c|c|c|c|c|c|c|}
\hline \multirow[t]{2}{*}{ Characteristics } & \multicolumn{2}{|c|}{ Non-Hispanic White $(n=989)$} & \multicolumn{2}{|c|}{ Non-Hispanic Black $(n=683)$} & \multicolumn{2}{|c|}{ Mexican American ( $n=741)$} & \multirow[t]{2}{*}{ P-value** } \\
\hline & $\mathbf{N}$ & Weighted ${ }^{* \%}$ (SE) & $\mathbf{N}$ & Weighted \% (SE) & $\mathbf{N}$ & Weighted \% (SE) & \\
\hline \multicolumn{8}{|l|}{ Age (years) } \\
\hline $17-39$ & 328 & $45.57(1.88)$ & 386 & $55.67(2.30)$ & 426 & $65.75(2.32)$ & $<.0001$ \\
\hline $40-59$ & 251 & $31.92(2.07)$ & 194 & $29.89(1.97)$ & 166 & $25.74(1.98)$ & \\
\hline$>=60$ & 410 & $22.51(1.88)$ & 103 & $14.45(2.02)$ & 149 & $8.51(1.11)$ & \\
\hline \multicolumn{8}{|l|}{ Sex } \\
\hline Male & 380 & $47.00(1.78)$ & 273 & $43.07(1.79)$ & 370 & $51.34(1.17)$ & 0.0053 \\
\hline Female & 609 & $53.00(1.78)$ & 410 & $56.93(1.79)$ & 371 & $48.66(1.17)$ & \\
\hline \multicolumn{8}{|l|}{ Education } \\
\hline$<$ High School & 246 & $18.26(1.60)$ & 225 & $30.40(2.83)$ & 445 & $57.56(2.84)$ & $<.0001$ \\
\hline High School & 363 & $35.71(1.83)$ & 252 & $37.23(2.57)$ & 176 & $25.64(2.22)$ & \\
\hline College and Above & 379 & $46.03(2.64)$ & 204 & $32.37(3.21)$ & 114 & $16.80(2.39)$ & \\
\hline \multicolumn{8}{|l|}{ Physical Activity } \\
\hline None & 195 & $16.69(1.47)$ & 199 & $28.74(2.60)$ & 256 & 31.35 (2.11) & $<.0001$ \\
\hline Low & 354 & $36.29(1.82)$ & 215 & $31.07(1.87)$ & 222 & 30.30 (1.75) & \\
\hline High & 440 & $47.02(2.50)$ & 269 & $40.19(2.71)$ & 263 & 38.35 (2.22) & \\
\hline \multicolumn{8}{|l|}{ Alcohol Intake } \\
\hline None & 536 & $45.67(2.63)$ & 375 & $55.16(1.75)$ & 376 & 48.25 (1.72) & 0.0268 \\
\hline$<4$ & 237 & $28.82(1.86)$ & 135 & $22.00(1.30)$ & 170 & $26.66(2.74)$ & \\
\hline$>=4$ & 198 & $25.51(1.83)$ & 145 & $22.84(1.44)$ & 174 & 25.09 (1.82) & \\
\hline \multicolumn{8}{|l|}{ Smoking Status } \\
\hline Current & 207 & $24.40(2.02)$ & 198 & $29.87(1.54)$ & 149 & 20.39 (1.65) & $<.0001$ \\
\hline Former & 291 & $28.36(1.57)$ & 87 & $13.43(1.48)$ & 161 & 19.34 (1.99) & \\
\hline \multirow[t]{2}{*}{ Non-smoker } & 491 & $47.24(2.36)$ & 398 & $56.70(1.91)$ & 431 & $60.26(1.67)$ & \\
\hline & $\mathbf{N}$ & Mean (SE) & $\mathbf{N}$ & Mean (SE) & $\mathbf{N}$ & Mean (SE) & P-value*** \\
\hline BMI & 989 & $26.40(0.20)$ & 683 & $28.17(0.28)$ & 739 & $27.83(0.25)$ & $<.0001$ \\
\hline Total Fat Intake $(\mathrm{g} / \text { day })^{* * * *}$ & 963 & $90.21(2.49)$ & 658 & $85.63(2.90)$ & 724 & $84.35(2.33)$ & 0.1826 \\
\hline Serum HDL (mg/dL) & 983 & $49.33(0.78)$ & 675 & $53.88(0.97)$ & 739 & $46.58(0.67)$ & 0.0001 \\
\hline Serum LDL (mg/dL) & 962 & $126.35(1.20)$ & 665 & $122.96(1.57)$ & 710 & $118.55(1.25)$ & 0.007 \\
\hline Total Cholesterol (mg/dL) & 985 & $202.07(1.46)$ & 677 & $197.91(1.39)$ & 739 & $193.37(1.49)$ & 0.004 \\
\hline Serum Triglycerides (mg/dL) & 984 & $138.73(4.82)$ & 677 & $107.27(2.36)$ & 738 & $146.67(4.29)$ & 0.0001 \\
\hline
\end{tabular}

adjusted models. Among non-Hispanic blacks, an inverse association was found in crude and adjusted analyses between the T-T ( $\varepsilon 2$ isoform) haplotype of $A P O E$ and LDL-C ( $p \leq 0.0010$ for both) and TC ( $p=0.052$ for crude; $p=0.0020$ for adjusted). In Mexican Americans, haplotypes of PON1 (A-A and A-G) were significantly associated with elevated HDL-C; and NOS3 haplotype T-T was significantly associated with decreased levels of LDL-C. In addition, carriers of the $A P O E \mathrm{C}-\mathrm{C}$ ( $\varepsilon 4$ isoform) haplotype had significantly increased LDL-C (borderline significant in crude model and strongly significant in adjusted model) and TC (in the adjusted model); whereas, $A P O E$ T-T $(\varepsilon 2)$ carriers had significantly decreased levels of LDL-C and TC (in adjusted models 
Table 2: Crude and adjusted associations between blood lipids and variants by race/ethnicity - NHANES III (1991-1994)

\begin{tabular}{|c|c|c|c|c|c|c|c|}
\hline \multirow[t]{2}{*}{ Genetic Variant } & \multicolumn{2}{|c|}{ Non-Hispanic White } & \multicolumn{2}{|c|}{ Non-Hispanic Black } & \multicolumn{2}{|c|}{ Mexican American } & \multirow{2}{*}{$\begin{array}{l}\text { SNP X Race/ethnicity } \\
\text { FDR-adjusted P value }\end{array}$} \\
\hline & $\beta(95 \% \mathrm{Cl})$ & FDR-adjusted P value* & $\beta(95 \% \mathrm{Cl})$ & FDR-adjusted $P$ value & $\beta(95 \% \mathrm{Cl})$ & FDR-adjusted $P$ value & \\
\hline \multicolumn{8}{|l|}{ Crude Analysis } \\
\hline \multicolumn{8}{|c|}{ High-density lipoprotein cholesterol } \\
\hline rs854560 (PON1) & $\begin{array}{c}-2.23 \\
(-5.15,0.69)\end{array}$ & 0.3589 & $\begin{array}{c}-0.58 \\
(-2.81,1.65)\end{array}$ & 0.869 & $\begin{array}{c}3.59 \\
(1.55,5.64)\end{array}$ & 0.0308 & 0.2552 \\
\hline \multicolumn{8}{|c|}{ Low-density lipoprotein cholesterol } \\
\hline rs7412 (APOE) & $\begin{array}{c}-16.68 \\
(-27.85,-5.50)\end{array}$ & 0.1144 & $\begin{array}{c}-20.58 \\
(-29.12,-12.04)\end{array}$ & $<.0001$ & $\begin{array}{c}-19.80 \\
(-33.33,-6.28)\end{array}$ & 0.066 & 0.8931 \\
\hline \multicolumn{8}{|c|}{ Total serum cholesterol } \\
\hline rs7412 (APOE) & $\begin{array}{c}-13.90 \\
(-25.39,-2.41)\end{array}$ & 0.1569 & $\begin{array}{c}-16.26 \\
(-25.75,-6.77)\end{array}$ & 0.0374 & $\begin{array}{c}-10.26 \\
(-19.18,-1.33)\end{array}$ & 0.2871 & 0.9227 \\
\hline \multicolumn{8}{|l|}{ Triglycerides } \\
\hline rs5918 (ITGB3) & $\begin{array}{c}0.05 \\
(-0.06,0.17)\end{array}$ & 0.7294 & $\begin{array}{c}0.14 \\
(0.07,0.20)\end{array}$ & 0.0066 & $\begin{array}{c}-0.05 \\
(-0.17,0.06)\end{array}$ & 0.613 & 0.4653 \\
\hline \multicolumn{8}{|c|}{ Adjusted Analysis** } \\
\hline \multicolumn{8}{|c|}{ High-density lipoprotein cholesterol } \\
\hline rs854560 (PON1) & $\begin{array}{c}-1.53 \\
(-4.11,1.06)\end{array}$ & 0.5062 & $\begin{array}{c}-0.09 \\
(-2.20,2.02)\end{array}$ & 0.9733 & $\begin{array}{c}3.21 \\
(1.45,4.97)\end{array}$ & 0.022 & 0.1535 \\
\hline \multicolumn{8}{|c|}{ Low-density lipoprotein cholesterol } \\
\hline rs7412 (APOE) & $\begin{array}{c}-16.87 \\
(-27.94,-5.81)\end{array}$ & 0.0968 & $\begin{array}{c}-22.52 \\
(-30.01,-15.04)\end{array}$ & $<.0001$ & $\begin{array}{c}-21.47 \\
(-31.32,-11.62)\end{array}$ & 0.0022 & 0.9012 \\
\hline rs429358 (APOE) & $\begin{array}{c}8.26 \\
(1.19,15.33)\end{array}$ & 0.264 & $\begin{array}{c}3.85 \\
(-2.14,9.84)\end{array}$ & 0.6169 & $\begin{array}{c}10.54 \\
(6.41,14.67)\end{array}$ & $<.0001$ & 0.9012 \\
\hline rs1799983 (NOS3) & $\begin{array}{c}3.05 \\
(-2.41,8.52)\end{array}$ & 0.5284 & $\begin{array}{c}5.28 \\
(-0.42,10.98)\end{array}$ & 0.4103 & $\begin{array}{c}-4.56 \\
(-7.63,-1.48)\end{array}$ & 0.0396 & 0.9012 \\
\hline \multicolumn{8}{|c|}{ Total serum cholesterol } \\
\hline rs7412 (APOE) & $\begin{array}{c}-15.26 \\
(-26.16,-4.36)\end{array}$ & 0.0902 & $\begin{array}{c}-20.68 \\
(-28.90,-12.47)\end{array}$ & $<.0001$ & $\begin{array}{c}-12.54 \\
(-19.89,-5.20)\end{array}$ & 0.0198 & 0.9724 \\
\hline rs429358 (APOE) & $\begin{array}{c}9.82 \\
(2.96,16.69)\end{array}$ & 0.0902 & $\begin{array}{c}4.35 \\
(-2.30,11.01)\end{array}$ & 0.6839 & $\begin{array}{c}11.18 \\
(7.11,15.25)\end{array}$ & $<.0001$ & 0.9724 \\
\hline \multicolumn{8}{|l|}{ Triglycerides } \\
\hline rs5918 (ITGB3) & $\begin{array}{c}0.02 \\
(-0.07,0.11)\end{array}$ & 0.8985 & $\begin{array}{c}0.14 \\
(0.09,0.19)\end{array}$ & $<.0001$ & $\begin{array}{c}-0.01 \\
(-0.14,0.11)\end{array}$ & 0.8962 & 0.4419 \\
\hline
\end{tabular}

$\beta$, beta coefficient; $\mathrm{Cl}$, confidence interval; FDR, false discovery rate

*P-value was based on Satterthwaite-adjusted $\mathrm{F}$ test and adjusted for multiple comparisons using false discovery rate within each race/ethnicity group.

**Adjusted for age, sex, education, body mass index, smoking status, alcohol intake, physical activity, dietary fat intake. 
Table 3: Crude and adjusted haplotype analysis for blood lipid levels by race/ethnicity - NHANES III (1991-1994)

\begin{tabular}{|c|c|c|c|c|c|c|c|}
\hline \multirow[t]{2}{*}{ Genetic Variant } & \multirow[t]{2}{*}{ Haplotype } & \multicolumn{2}{|c|}{ Non-Hispanic White } & \multicolumn{2}{|c|}{ Non-Hispanic Black } & \multicolumn{2}{|c|}{ Mexican American } \\
\hline & & $\beta(95 \% \mathrm{Cl})$ & FDR-adjusted P value* & $\beta(95 \% \mathrm{Cl})$ & FDR-adjusted P value & $\beta(95 \% \mathrm{Cl})$ & FDR-adjusted $P$ \\
\hline \multicolumn{8}{|c|}{ High-density lipoprotein cholesterol } \\
\hline \multirow[t]{3}{*}{ PON1 } & $A-A$ & $\begin{array}{c}-6.56 \\
(-13.78,0.66)\end{array}$ & 0.3814 & $\begin{array}{c}-0.91 \\
(-8.16,6.35)\end{array}$ & 0.9641 & $\begin{array}{c}6.81 \\
(2.89,10.73)\end{array}$ & 0.0179 \\
\hline & T-A & $\begin{array}{c}-3.75 \\
(-7.46,-0.05)\end{array}$ & 0.3814 & $\begin{array}{c}-0.12 \\
(-5.58,5.34)\end{array}$ & 0.9641 & $\begin{array}{c}1.03 \\
(-3.09,5.14)\end{array}$ & 0.8002 \\
\hline & $\mathrm{T}-\mathrm{G}$ & REF & & REF & & REF & \\
\hline \multicolumn{8}{|c|}{ Low-density lipoprotein cholesterol } \\
\hline \multirow[t]{2}{*}{$A P O E$} & $\mathrm{C}-\mathrm{C}$ & $\begin{array}{c}12.12 \\
(-4.40,28.64)\end{array}$ & 0.2499 & $\begin{array}{c}4.92 \\
(-5.58,15.41)\end{array}$ & 0.9016 & $\begin{array}{c}15.43 \\
(5.73,25.14)\end{array}$ & 0.0494 \\
\hline & $\mathrm{T}-\mathrm{C}$ & REF & & REF & & REF & \\
\hline \multirow[t]{4}{*}{ NOS3 } & C-G & $\begin{array}{c}-6.17 \\
(-19.32,6.98)\end{array}$ & 0.4971 & $\begin{array}{c}2.26 \\
(-15.53,20.05)\end{array}$ & 0.9861 & $\begin{array}{c}-0.62 \\
(-10.80,9.56)\end{array}$ & 0.9665 \\
\hline & $C-T$ & $\begin{array}{c}3.85 \\
(-11.06,18.76)\end{array}$ & 0.7161 & $\begin{array}{c}38.05 \\
(4.28,71.81)\end{array}$ & 0.1927 & $\begin{array}{c}0.24 \\
(-11.33,11.80)\end{array}$ & 0.9665 \\
\hline & T-G & REF & & REF & & REF & \\
\hline & $\mathrm{T}-\mathrm{T}$ & $\begin{array}{c}0.82 \\
(-23.44,25.08)\end{array}$ & 0.9704 & $\begin{array}{c}2.94 \\
(-11.50,17.37)\end{array}$ & 0.9861 & $\begin{array}{c}-20.78 \\
(-34.52,-7.03)\end{array}$ & 0.0494 \\
\hline \multirow[t]{4}{*}{ PON1 } & $A-A$ & $\begin{array}{c}10.91 \\
(-0.74,22.56)\end{array}$ & 0.1706 & $\begin{array}{c}4.89 \\
(-12.82,22.60)\end{array}$ & 0.9861 & $\begin{array}{c}2.45 \\
(-9.04,13.94)\end{array}$ & 0.8789 \\
\hline & $A-G$ & $\begin{array}{c}46.49 \\
(21.16,71.82)\end{array}$ & 0.0063 & $\begin{array}{c}8.91 \\
(-12.85,30.68)\end{array}$ & 0.9016 & $\begin{array}{c}6.44 \\
(-25.95,38.84)\end{array}$ & 0.8789 \\
\hline & T-A & $\begin{array}{c}8.98 \\
(-2.58,20.53)\end{array}$ & 0.247 & $\begin{array}{c}-1.09 \\
(-11.58,9.40)\end{array}$ & 0.9861 & $\begin{array}{c}-2.04 \\
(-8.21,4.13)\end{array}$ & 0.8789 \\
\hline & T-G & REF & & REF & & REF & \\
\hline \multicolumn{8}{|c|}{ Total serum cholesterol } \\
\hline \multirow{2}{*}{$A P O E$} & $\mathrm{~T}-\mathrm{C}$ & REF & & REF & & REF & \\
\hline & $\mathrm{T}-\mathrm{T}$ & $\begin{array}{c}-24.87 \\
(-51.22,1.48)\end{array}$ & 0.2172 & $\begin{array}{c}-31.33 \\
(-50.53,-12.13)\end{array}$ & 0.052 & $\begin{array}{c}-19.40 \\
(-38.15,-0.64)\end{array}$ & 0.3143 \\
\hline
\end{tabular}


Table 3: Crude and adjusted haplotype analysis for blood lipid levels by race/ethnicity - NHANES III (1991-1994) (Continued)

\section{Adjusted Analysis*}

High-density lipoprotein cholesterol

PON1

$\begin{array}{cc}\text { A-A } & -4.86 \\ & (-11.20,1.48) \\ \text { A-G } & -5.79 \\ & (-14.56,2.98) \\ \text { T-A } & -3.22 \\ & (-6.60,0.17) \\ \text { T-G } & \text { REF }\end{array}$

APOE

$\mathrm{C}-\mathrm{C}$

NOS3

$1-C$

12

REF

$$
\text { REF }
$$

$-3.42(-15.49,8.65)$
Low-density lipoprotein cholesterol
0.4856

0.4856

0.4856

$-31.14(-56.65,-5.64)$

$6.48(-10.27,23.22)$

REF

$1.64(-20.75,24.03)$

$8.77(-5.24,22.77)$

$40.03(19.65,60.41)$

$9.78(-0.77,20.33)$

REF

0.0053

0.2366

-1.92
$(-9.08,5.24)$
2.17
$(-5.89,10.24)$
$1.52(-4.67,7.71)$

REF

$4.01(-8.26,16.28)$

REF

$-44.33(-59.39,-29.27)$

$2.68(-13.71,19.06)$

$31.18(4.64,57.72)$

REF

$1.95(-10.32,14.21)$

$8.10(-9.66,25.85)$

$10.90(-12.43,34.24)$

$-2.95(-13.93,8.03)$

REF

\section{Total serum cholesterol}

0.8857

0.8857

0.8857

6.14
$(3.44,8.84)$

19.62

$(6.84,32.39)$

$1.23(-2.73,5.20)$

REF

0.8555

$21.28(13.93,28.64)$

REF

$<.0001$

0.8555

0.233

0.8555

0.8555

0.8555

0.8555

0.8062

0.002

$-3.05(-8.55,2.46)$

$-0.69(-10.02,8.64)$

REF

REF

$-25.23(-39.80,-10.66)$
$\mathrm{T}-\mathrm{C}$

$$
\begin{gathered}
16.52(0.51,32.53) \\
\text { REF }
\end{gathered}
$$

$$
-27.18(-52.46,-1.90)
$$

0.153

$$
\begin{gathered}
5.32(-8.35,18.99) \\
\text { REF }
\end{gathered}
$$$$
0.153
$$

$-43.23(-64.13,-22.34)$

$-32.14(-47.72,-16.55) \quad 0.0016$

$-2.54(-15.41,10.32) \quad 0.8479$

$9.62(-21.64,40.88) \quad 0.7428$

$-3.33(-12.53,5.87) \quad 0.7428$

\section{$22.41(14.73,30.10)$ \\ REF}

$<.000$

$\beta$, beta coefficient; $\mathrm{Cl}$, confidence interval; REF reference group.

*P-value was based on Satterthwaite-adjusted $\mathrm{F}$ test and adjusted for multiple comparisons using false discovery rate within each race/ethnicity group.

**Adjusted for age, sex, education, body mass index, smoking status, alcohol intake, physical activity, dietary fat intake. 
only). The A-G haplotype of $A D R B 2$ was significantly associated with elevated HDL-C (in crude and adjusted models) among Mexican Americans (see Additional Tables S5a and S6a). However, the confidence intervals were relatively wide. Rare haplotypes (which were combined and coded as "other") of MTHFR and TNF were associated with blood lipids in at least one race/ethnic group (Additional file 1, Tables S5a-d, S6a-d). There were no common haplotypes significantly associated with TG levels in any race/ethnic group.

\section{Discussion}

In this study, we evaluated statistical associations between blood lipid levels and candidate genes involved in a number of biological pathways, such as nutrient metabolism, immune response and inflammation, oxidative stress, and homeostasis. To our knowledge, there is only one other study (i.e., Keebler et al.) [40] published that describes genetic associations with blood lipid levels using a nationally representative sample of the U.S. population. This study also used data from the NHANES III survey, but associations were examined at 19 genomewide validated loci on fasting and nonfasting samples. Those data were not available for our use while the present study was being conducted. We examined a different set of polymorphisms which had been identified previously through candidate gene association studies. In our analyses, we used only fasting samples in accordance with guidelines from The National Cholesterol Education Program (NCEP) Expert Panel on Detection, Evaluation, and Treatment of High Blood Cholesterol in Adults (Adult Treatment Panel III, ATPIII) [34].

Our findings suggest, before and after adjustment for numerous demographic and behavioral characteristics in one or more race/ethnic groups, that blood lipid levels differ by an increasing number of minor alleles of polymorphisms in APOE, ITGB3, NOS3, and PON1. Our results also show that the A-G haplotype of $A D R B 2$ was associated with elevated HDL-C among Mexican Americans. However, these results from crude and adjusted models are unstable (wide confidence intervals) and would need more data collected to support the association. We found that the group of rare haplotypes (frequency <1\%) within MTHFR and TNF were associated with several blood lipids across race/ethnic groups; but, we are unable to identify which rare haplotype(s) contribute to these findings. Consequently, we cannot interpret these associations.

In analyses of individual variants and of haplotypes, we found strong statistical associations between genetic variation in APOE and LDL-C and TC levels in non-Hispanic blacks and Mexican Americans. APOE, one of the most studied genes in risk assessment of cardiovascular disease, plays a key role in the metabolism of cholesterol and triglycerides by binding to receptors on the liver and helping to mediate the clearance of chylomicrons and very low-density lipoproteins from the bloodstream [4146]. Allelic variation in $A P O E$ has been associated consistently with plasma concentrations of total cholesterol and LDL cholesterol [42,47], and with protein levels of APOB (the major protein of LDL, VLDL, and chylomicrons).

Our findings suggested an association of the NOS3 rs1799983 variant and T-T haplotype with LDL-C in Mexican Americans. NOS3 serves as a key enzyme of the endogenous nitrovasodilator system, which is essential for the regulation of vascular function and blood pressure, through the production of nitric oxide. The Glu298Asp variant (rs1799983) has been significantly associated with higher plasma LDL cholesterol, LDL particle size, and lower plasma HDL cholesterol; but no significant associations were found with the T-786C variant [48]. Numerous studies have also reported a positive association with the Glu298Asp variant and haplotypes containing this variant with higher triglycerides and LDL cholesterol in Venezuelans [49] and Greeks [50].

We found higher HDL-C among Mexican American carriers of the PON1 rs854560 (Leu55Met) variant and A-A and A-G haplotypes. Conversely, we found higher LDL-C in non-Hispanic white carriers of the A-G haplotype. PON1 is an HDL-associated esterase that hydrolyzes products of lipid peroxidation and prevents the oxidation of HDL and LDL. In fact, the antioxidant activity and anti-atherogenic effect of HDL is thought to be largely because of the paraoxonase located on the HDL particle. Variants in PON1 previously have been associated with serum HDL and LDL cholesterol levels [51,52], and with increased risk for stroke [53]. There have been multiple studies and meta-analyses evaluating the association of PON1 variants with blood lipids in several populations or community-based samples, but with inconsistent results [51,54-61].

Our results suggest a strong association of ITGB3 with triglycerides in non-Hispanic blacks. ITGB3 is a membrane receptor for fibrinogen and von Willebrand factor that has an important role in platelet aggregation. The Pro33 allele (rs5918) has been associated with coronary thrombosis $[62,63]$ and stroke $[64,65]$. A previous study examined associations between 15 single nucleotide polymorphisms across ITGB3 and cardiovascular diseaserelated traits in the Hutterites (e.g., plasma levels of HDL and LDL cholesterol and triglycerides) and suggested that ITGB3 has sex-specific associations with plasma lipoprotein(a) [66].

Although we did not assess racial/ethnic difference in the genetic effects, we observed that two associations, both involving the rs7412 variant in $A P O E$, were significant in two racial/ethnic groups. No variants were significant across all three racial/ethnic groups after the FDR 
adjustment. Limited power and statistical chance may explain, at least, in part, the lack of consistent findings across the three race/ethnicities. Alternatively, these differences may be caused by varying linkage disequilibrium patterns at causal loci across different race/ethnic populations or by gene-environment interactions that have not been identified or measured. As a result, it might not be unusual to find varying risks for a disease or trait at a given genomic locus across population subgroups. In agreement, a recent study examined 12 newly discovered genetic variants known to predict lipid levels in Europeans and also evaluated local ancestry at validated genes that influence lipid levels [67]. This study found genetic differences between the determinants of lipid phenotypes across different African and European populations. Such findings might suggest that many of the truly causal variants in different race/ethnic groups have yet to be discovered, as most genetic epidemiology studies have been performed in populations of European descent.

Although we identified associations of APOE, ITGB3, $N O S 3$, and PON1 with blood lipid levels by examining polymorphisms individually, our results suggest that assessing genetic variation using haplotype methods might be more comprehensive and more informative. We found that although a single genetic variant might have a small (if any) effect in identifying a susceptibility locus for an outcome, the effect might reach statistical significance when combined with other variants within the gene. For example, after adding a single variant ( $A P O E$ rs7412) to a regression model containing non-genetic risk factors, we were able to explain only slightly more variation in LDL$C\left(R^{2}=0.1448\right.$ for non-Hispanic white persons, 0.2065 for non-Hispanic black persons, and 0.1462 for Mexican American persons) compared to the variation explained by non-genetic risk factors alone $\left(\mathrm{R}^{2}=0.1163,0.1533\right.$, and 0.1230 , respectively). However, we observed that a larger proportion of the variation in LDL-C is explained by the model that contains the APOE T-T haplotype compared to the model containing the rs7412 variant alone $\left(\mathrm{R}^{2}=\right.$ $0.1521,0.2073$, and 0.1636, respectively). Overall, the variance in blood lipid levels explained by the contribution of each individual variant or haplotype is considerably small ( $<5 \%$; data not shown).

The present study has many notable strengths. First, the study was conducted using a large population-based and nationally representative survey of the United States. The wealth of data in NHANES facilitated the examination of genetic, environmental, and clinical data for each of the three major race/ethnicities in the United States. Moreover, whereas many previous reports were limited to a single population or were based on smaller study populations, we were able to conduct the analyses separately in each race/ethnicity, and were therefore able to account for the differences in allele frequencies, disease prevalence, and linkage disequilibrium patterns between these subpopulations. Finally, the control of hypercholesterolemia is an important clinical and public health objective. Awareness of, and screening for, hypercholesterolemia have become more common in recent years. Accordingly, treatment of the condition has increased since the initiation of the National Cholesterol Education Program in 1985. The use of cholesterol-lowering medications has increased steadily in U.S. adults aged $\geq 20$ years, from $8.2 \%$ in $1999-2000$ to $14.0 \%$ in $2005-2006$, as measured in NHANES [68]. Among those diagnosed with hypercholesterolemia, the proportion on treatment increased from $32.4 \%$ to $38.9 \%$ in the 8 -year period from 1999 to 2006 [69]. Association analyses of genetic variants involved in influencing blood lipid levels may therefore be complicated by a high prevalence of study participants who take lipid-lowering drugs. An advantage of this study in NHANES III is that a small number of participants taking such medication needed to be excluded ( $\mathrm{n}=75 ; 3 \%$ of fasting samples). Evaluation of such genetic associations in subsequent NHANES surveys will result in a loss of a higher number of participants in the analyses.

In addition to these strengths, we acknowledge several limitations. To help reduce the chance of potential falsepositive results from multiple testing, we adjusted $\mathrm{p}$-values to control the false discovery rate [39]. This method assumes that the set of tests are independent. Yet, we know that many of the test statistics might be correlated because of linkage disequilibrium between genetic variants [70]. The FDR adjustment, therefore, might result in overly conservative p-values, thus decreasing our ability to identify true associations.

Although we stratified the analysis by race/ethnicity, we cannot eliminate completely the possibility of confounding of our study results by population stratification. We were not able to assess population structure in our analysis and grouped participants by broad categories on the basis of self-reported race and ethnicity. Substantial admixture in the African American and Hispanic populations has been documented [71-74]. However, previous research conducted on the U.S. population has found little evidence for population substructure in whites [75].

Although the NHANES III data may be more representative of the U.S. population than other non-populationbased samples, the statistical power to detect genetic associations was limited in this study. For example, we determined the beta-coefficients that correspond to the genetic variant explaining $1 \%$ of the variation in LDL-C. The beta-coefficients ranged from 5.2 to 26.3 depending on the frequency of the minor allele (MAF $=0.01$ to 0.5 ). Using these beta-coefficients and corresponding allele frequencies described above for LDL-C, we found that our power would be $42-82 \%$ for non-Hispanic whites, 24- 
$66 \%$ for non-Hispanic blacks, and $27-70 \%$ for Mexican Americans (Additional file 1, Table S7).

\section{Conclusions}

We report the significant association of blood lipid levels with variants and haplotypes in APOE, ITGB3, NOS3, and PON1 in multiple race/ethnic groups in the United States, using a large, nationally representative and population-based sample survey. Because of strengths of the study design, these findings could be generalized to the U.S. population. Results from our study contribute to a growing body of literature identifying key determinants of plasma lipoprotein concentrations and might provide insight into the biological mechanisms underlying serum lipid and cholesterol concentrations.

\section{Additional material}

Additional file 1 Table S1. Allele frequencies by race/ethnicity - NHANES III (1991-1994). The allele frequencies by race/ethnicity are shown. Table S2. P-Values from the Univariate analysis for covariates - NHANES III (19911994). The $p$-values from the univariate analysis of covariates are shown. Table S3a-d. Univariate analysis for HDL-C, LDL-C, TC, and TG, and candidate genetic variants by race/ethnicity - NHANES III (1991-1994). The univariate analysis for lipids and candidate genetic variants by race/ethnicity is shown. Table S4a-d. Association between HDL-C, LDL-C, TC, and TG, and selected genetic variants adjusting for covariates by race/ethnicity - NHANES III (1991-1994). The association, by race/ethnicity, between lipdis and selected genetic variants adjusting for covariates are shown. Table S5a-d. Crude hap lotype analysis for HDL-C, LDL-C, TC, and TG, by race/ethnicity - NHANES III (1991-1994). The crude haplotype analysis for lipids by race/ethnicity is shown. Table S6a-d. Adjusted haplotype analysis for HDL-C, LDL-C, TC, and TG, by race/ethnicity - NHANES III (1991-1994). The adjusted haplotype analysis for lipids by race/ethnicity is shown. Table S7. Power calculation by race/ethnicity - NHANES III (1991-1994). Power calculation by race/ethnicity is shown.

\section{Abbreviations}

CDC: Centers for Disease Control and Prevention; Cl: confidence interval; FDR false-discovery rate; HDL-C: high-density lipoprotein cholesterol; LDL-C: lowdensity lipoprotein cholesterol; MAF: minor allele frequencies; NCHS: National Center for Health Statistics; NHANES III: Third National Health and Nutrition Examination Survey; NOPHG: National Office of Public Health Genomics; SNP: single nucleotide polymorphism; TC: total cholesterol; TG: triglycerides.

\section{Competing interests}

The authors declare that they have no competing interests.

\section{Authors' contributions}

MC led the development of the analytic plan, worked closely with AY in the analyses of the data, interpreted the findings, and drafted the manuscript. AY developed the statistical methods and conducted the data analyses. RMN performed literature reviews, provided genotyping and genetic consultation, and performed editorial review. PWM conceived of the original research question, gave critical input on research methods, and helped to interpret the findings. NFD serves as Team Lead of the Population Health Research Team in the National Office of Public Health Genomics (NOPHG) and oversees the CDC/NCl NHANES III Genomics Working Group. NFD provided scientific leadership for development of the research plan, interpretation of findings, and helped write the manuscript. All authors read and approved the final manuscript.

\section{Acknowledgements}

The findings and conclusions in this report are those of the authors and do not necessarily represent the official position of the Centers for Disease Control and Prevention. Special thanks to Muin J. Khoury, MD, PhD (Director of NOPHG) for oversight of the project, members of NOPHG for critical comments, and staff at the Research Data Center in the National Center for Health Statistics for their data support and assistance in disclosure review. This project was completed in partnership with the CDC/NCI NHANES III Genomics Working Group.

\section{Author Details}

'National Office of Public Health Genomics, Centers for Disease Control and Prevention, Atlanta, GA, USA and 2 National Center for Environmental Health, Centers for Disease Control and Prevention, Atlanta, GA, USA

Received: 8 October 2009 Accepted: 20 April 2010

Published: 20 April 2010

\section{References}

1. National Institutes of Health: Third Report of the National Cholesterol Education Program (NCEP) Expert Panel on Detection, Evaluation, and Treatment of High Blood Cholesterol in Adults (Adult Treatment Panel III) final report. Circulation 2002, 106(25):3143-3421.

2. Rywik SL, Manolio TA, Pajak A, Piotrowski W, Davis CE, Broda GB, Kawalec E: Association of lipids and lipoprotein level with total mortality and mortality caused by cardiovascular and cancer diseases (Poland and United States collaborative study on cardiovascular epidemiology). Am J Cardiol 1999, 84(5):540-548.

3. Bray M: Genetic and environmental factors in cardiovascular disease. In Human Genome Epidemiology Edited by: Khoury M, Little J, Burke W. New York: Oxford University Press, Inc; 2004:436-450.

4. Briel M, Ferreira-Gonzalez I, You JJ, Karanicolas PJ, AkI EA, Wu P, Blechacz B, Bassler D, Wei X, Sharman A, Whitt I, Alves da Silva S, Khalid Z, Nordmann AJ, Zhou Q, Walter SD, Vale N, Bhatnagar N, O'Regan C, Mills EJ, Bucher HC, Montori VM, Guyatt GH: Association between change in high density lipoprotein cholesterol and cardiovascular disease morbidity and mortality: systematic review and meta-regression analysis. BMJ 2009, 338:b92.

5. Asztalos BF, Cupples LA, Demissie S, Horvath KV, Cox CE, Batista MC, Schaefer EJ: High-density lipoprotein subpopulation profile and coronary heart disease prevalence in male participants of the Framingham Offspring Study. Arterioscler Thromb Vasc Biol 2004, 24(11):2181-2187.

6. Castelli WP: Epidemiology of triglycerides: a view from Framingham. Am J Cardiol 1992, 70(19):3H-9H.

7. Castelli WP: The role of plasma lipids as predictors of risk for coronary heart disease. Drugs 1990, 40(Suppl 1):1-4. discussion 5-6.

8. Castelli WP, Anderson K, Wilson PW, Levy D: Lipids and risk of coronary heart disease. The Framingham Study. Ann Epidemiol 1992, 2(12):23-28.

9. Heller DA, de Faire U, Pedersen NL, Dahlen G, McClearn GE: Genetic and environmental influences on serum lipid levels in twins. N Engl J Med 1993, 328(16):1150-1156.

10. Namboodiri KK, Kaplan EB, Heuch I, Elston RC, Green PP, Rao DC, Laskarzewski P, Glueck CJ, Rifkind BM: The Collaborative Lipid Research Clinics Family Study: biological and cultural determinants of familial resemblance for plasma lipids and lipoproteins. Genet Epidemiol 1985 2(3):227-254.

11. Spielmann N, Leon AS, Rao DC, Rice T, Skinner JS, Bouchard C, Rankinen T: CETP genotypes and HDL-cholesterol phenotypes in the HERITAGE Family Study. Physiol Genomics 2007, 31(1):25-31.

12. Choquette AC, Bouchard L, Houde A, Bouchard C, Perusse L, Vohl MC: Associations between USF1 gene variants and cardiovascular risk factors in the Quebec Family Study. Clin Genet 2007, 71(3):245-253.

13. Garenc C, Aubert S, Laroche J, Bergeron J, Gagne C, Rousseau F, Julien P: Gene polymorphisms in the Quebec population: a risk to develop hypertriglyceridemia. Biochem Biophys Res Commun 2006, 344(2):588-596

14. Pallaud C, Gueguen R, Sass C, Grow M, Cheng S, Siest G, Visvikis S: Genetic influences on lipid metabolism trait variability within the Stanislas Cohort. J Lipid Res 2001, 42(11):1879-1890.

15. Petrone A, Zavarella S, lacobellis G, Zampetti S, Vania A, Di Pietro S, Galgani A, Leonetti F, Di Mario U, Buzzetti R: Association of beta2 adrenergic receptor polymorphisms and related haplotypes with triglyceride and LDL-cholesterol levels. Eur J Hum Genet 2006, 14(1):94-100. 
16. Dedoussis GV, Maumus S, Choumerianou DM, Skoumas J, Pitsavos C, Stefanadis C, Visvikis-Siest S: Different genes and polymorphisms affecting high-density lipoprotein cholesterol levels in Greek familial hypercholesterolemia patients. Genet Test 2006, 10(3):192-199.

17. Pollin TI, Damcott CM, Shen H, Ott SH, Shelton J, Horenstein RB, Post W, McLenithan JC, Bielak LF, Peyser PA, Mitchell BD, Miller M, O'Connell JR, Shuldiner AR: A null mutation in human APOC3 confers a favorable plasma lipid profile and apparent cardioprotection. Science 2008, 322(5908):1702-1705

18. Aulchenko YS, Ripatti S, Lindqvist I, Boomsma D, Heid IM, Pramstaller PP, Penninx BW, Janssens AC, Wilson JF, Spector T, Martin NG, Pedersen NL, Kyvik KO, Kaprio J, Hofman A, Freimer NB, Jarvelin MR, Gyllensten U, Campbell H, Rudan I, Johansson A, Marroni F, Hayward C, Vitart V, Jonasson I, Pattaro C, Wright A, Hastie N, Pichler l, Hicks AA, et al:: Loci influencing lipid levels and coronary heart disease risk in 16 European population cohorts. Nat Genet 2009, 41(1):47-55.

19. Kathiresan S, Willer CJ, Peloso GM, Demissie S, Musunuru K, Schadt EE, Kaplan L, Bennett D, Li Y, Tanaka T, Voight BF, Bonnycastle LL, Jackson AU, Crawford G, Surti A, Guiducci C, Burtt NP, Parish S, Clarke R, Zelenika D, Kubalanza KA, Morken MA, Scott LJ, Stringham HM, Galan P, Swift AJ, Kuusisto J, Bergman RN, Sundvall J, Laakso M, et al.: Common variants at 30 loci contribute to polygenic dyslipidemia. Nat Genet 2009, 41(1):56-65.

20. Sabatti C, Service SK, Hartikainen AL, Pouta A, Ripatti S, Brodsky J, Jones CG, Zaitlen NA, Varilo T, Kaakinen M, Sovio U, Ruokonen A, Laitinen J, Jakkula E, Coin L, Hoggart C, Collins A, Turunen H, Gabriel S, Elliot P, McCarthy MI, Daly MJ, Järvelin MR, Freimer NB, Peltonen L: Genome-wide association analysis of metabolic traits in a birth cohort from a founder population. Nat Genet 2009, 41(1):35-46.

21. Burkhardt R, Kenny EE, Lowe JK, Birkeland A, Josowitz R, Noel M, Salit J, Maller JB, Pe'er I, Daly MJ, Altshuler D, Stoffel M, Friedman JM, Breslow JL: Common SNPs in HMGCR in micronesians and whites associated with LDL-cholesterol levels affect alternative splicing of exon13. Arterioscler Thromb Vasc Biol 2008, 28(11):2078-2084.

22. Sandhu MS, Waterworth DM, Debenham SL, Wheeler E, Papadakis K, Zhao JH, Song K, Yuan X, Johnson T, Ashford S, Inouye M, Luben R, Sims M, Hadley D, McArdle W, Barter P, Kesäniemi YA, Mahley RW, McPherson R, Grundy SM, Wellcome Trust Case Control Consortium, Bingham SA, Khaw KT, Loos RJ, Waeber G, Barroso I, Strachan DP, Deloukas P, Vollenweider P, Wareham NJ, et al:: LDL-cholesterol concentrations: a genome-wide association study. Lancet 2008, 371(9611):483-491.

23. Kathiresan S, Melander O, Guiducci C, Surti A, Burtt NP, Rieder MJ, Cooper GM, Roos C, Voight BF, Havulinna AS, Wahlstrand B, Hedner T, Corella D, Tai ES, Ordovas JM, Berglund G, Vartiainen E, Jousilahti P, Hedblad B, Taskinen MR, Newton-Cheh C, Salomaa V, Peltonen L, Groop L, Altshuler DM, Orho-Melander M: Six new loci associated with blood low-density lipoprotein cholesterol, high-density lipoprotein cholesterol or triglycerides in humans. Nat Genet 2008, 40(2):189-197.

24. Wallace C, Newhouse SJ, Braund P, Zhang F, Tobin M, Falchi M, Ahmadi K, Dobson RJ, Marçano AC, Hajat C, Burton P, Deloukas P, Brown M, Connell JM, Dominiczak A, Lathrop GM, Webster J, Farrall M, Spector T, Samani NJ, Caulfield MJ, Munroe PB: Genome-wide association study identifies genes for biomarkers of cardiovascular disease: serum urate and dyslipidemia. Am J Hum Genet 2008, 82(1):139-149.

25. Saxena R, Voight BF, Lyssenko V, Burtt NP, de Bakker PI, Chen H, Roix JJ, Kathiresan S, Hirschhorn JN, Daly MJ, Hughes TE, Groop L, Altshuler D, Almgren P, Florez JC, Meyer J, Ardlie K, Bengtsson Boström K, Isomaa B, Lettre G, Lindblad U, Lyon HN, Melander O, Newton-Cheh C, Nilsson P, Orho-Melander M, Råstam L, Speliotes EK, Taskinen MR, Tuomi T, et al:: Genome-wide association analysis identifies loci for type 2 diabetes and triglyceride levels. Science 2007, 316(5829):1331-1336.

26. Tabet $F$, Rye KA: High-density lipoproteins, inflammation and oxidative stress. Clin Sci (Lond) 2009, 116(2):87-98.

27. Garces C, Lopez-Simon L, Rubio R, Benavente M, Cano B, Ortega H, de Oya M: High-density lipoprotein cholesterol and paraoxonase 1 (PON1) genetics and serum PON1 activity in prepubertal children in Spain. Clin Chem Lab Med 2008, 46(6):809-813.

28. National Center for Health Statistics, Centers for Disease Control and Prevention: Plan and Operation of the Third National Health and Nutrition Examination Survey, 1988-94. Hyattsville, MD. National Center for Health Statistics, 1994. Vital and Health Statistics, Series 1: Programs and Collection Procedures, no. 32. DHHS publication no.
(PHS) 94-1308. 1994 [http://www.cdc.gov/nchs/data/series/sr $01 /$ sr01 032.pdf.

29. NHANES III Data Files, Documentation, and SAS Code http:// www.cdc.gov/nchs/nhanes/nh3data.htm]

30. NHANES Genetic Data [http://www.cdc.gov/nchs/nhanes/genetics/ genetic.htm]

31. Chang MH, Lindegren ML, Butler MA, Chanock SJ, Dowling NF, Gallagher M, Moonesinghe R, Moore CA, Ned RM, Reichler MR, Sanders CL, Welch R, Yesupriya A, Khoury MJ, CDC/NCI NHANES III Genomics Working Group: Prevalence in the United States of selected candidate gene variants: Third National Health and Nutrition Examination Survey, 1991-1994. Am J Epidemiol 2009, 169(1):54-66.

32. Gunter E, Lewis B, Koncikowski S: Laboratory procedures used for the third National Health and Nutrition Examination Survey (NHANES III), 1988-1994. 1996 [http://www.cdc.gov/nchs/data/nhanes/nhanes3/ cdrom/nchs/manuals/labman.pdf]. Atlanta, GA and Hyattsville, MD: National Center for Environmental Health and National Center for Health Statistics, Centers for Disease Control and Prevention

33. National Center for Health Statistics, Centers for Disease Control and Prevention. Third National Health and Nutrition Examination Survey (NHANES III), 1988-94: HNANES III Laboratory Data File Documentation. Catalog Number 763002006 [ftp://ftp.cdc.gov/pub/Health Statistics/ NCHS/Datasets/NHANES/NHANESIII/1A/lab-acc.pdf].

34. Executive Summary of The Third Report of The National Cholesterol Education Program (NCEP) Expert Panel on Detection, Evaluation, And Treatment of High Blood Cholesterol In Adults (Adult Treatment Panel III). JAMA 2001, 285(19):2486-2497.

35. Dempster A, Laird N, Rubin D: Maximum likelihood from incomplete data via the EM algorithm. J Royal Statistical Society 1977, Series B; 39(1):1-38.

36. Schaid DJ: Genetic epidemiology and haplotypes. Genet Epidemiol 2004, 27(4):317-320

37. Zaykin DV, Westfall PH, Young SS, Karnoub MA, Wagner MJ, Ehm MG: Testing association of statistically inferred haplotypes with discrete and continuous traits in samples of unrelated individuals. Hum Hered 2002, 53(2):79-91

38. Schaid DJ: Evaluating associations of haplotypes with traits. Genet Epidemiol 2004, 27(4):348-364

39. Benjamini $Y$, Hochberg $Y$ : Controlling the false discovery rate: a practical and powerful approach to multiple testing. J Royal Stat Soc 1995, Series $\mathrm{B}(57): 12$.

40. Keebler ME, Sanders CL, Surti A, Guiducci C, Burtt NP, Kathiresan S: Association of blood lipids with common DNA sequence variants at 19 genetic loci in the multiethnic United States National Health and Nutrition Examination Survey III. Circ Cardiovasc Genet 2009:238-243.

41. Eichner JE, Dunn ST, Perveen G, Thompson DM, Stewart KE, Stroehla BC Apolipoprotein E polymorphism and cardiovascular disease: a HuGE review. Am J Epidemiol 2002, 155(6):487-495

42. Bennet AM, Di Angelantonio E, Ye Z, Wensley F, Dahlin A, Ahlbom A Keavney B, Collins R, Wiman B, de Faire U, Danesh J: Association of apolipoprotein $\mathrm{E}$ genotypes with lipid levels and coronary risk. JAMA 2007, 298(11):1300-1311.

43. Mahley RW: Apolipoprotein E: cholesterol transport protein with expanding role in cell biology. Science 1988, 240(4852):622-630

44. Davignon J, Gregg RE, Sing CF: Apolipoprotein E polymorphism and atherosclerosis. Arteriosclerosis 1988, 8(1):1-21.

45. Song Y, Stampfer MJ, Liu S: Meta-analysis: apolipoprotein E genotypes and risk for coronary heart disease. Ann Intern Med 2004, 141(2):137-147.

46. Sudlow C, Martinez Gonzalez NA, Kim J, Clark C: Does apolipoprotein E genotype influence the risk of ischemic stroke, intracerebral hemorrhage, or subarachnoid hemorrhage? Systematic review and meta-analyses of 31 studies among 5961 cases and 17,965 controls. Stroke 2006, 37(2):364-370.

47. Willer CJ, Sanna S, Jackson AU, Scuteri A, Bonnycastle LL, Clarke R, Heath SC, Timpson NJ, Najjar SS, Stringham HM, Strait J, Duren WL, Maschio A, Busonero F, Mulas A, Albai G, Swift AJ, Morken MA, Narisu N, Bennett D, Parish S, Shen H, Galan P, Meneton P, Hercberg S, Zelenika D, Chen WM, Li $Y$, Scott $L$, Scheet PA, et al:: Newly identified loci that influence lipid concentrations and risk of coronary artery disease. Nat Genet 2008, 40(2):161-169. 
48. Imamura A, Takahashi R, Murakami R, Kataoka H, Cheng XW, Numaguchi $Y$, Murohara T, Okumura K: The effects of endothelial nitric oxide synthase gene polymorphisms on endothelial function and metabolic risk factors in healthy subjects: the significance of plasma adiponectin levels. Eur J Endocrinol 2008, 158(2):189-195.

49. Hoffmann IS, Tavares-Mordwinkin R, Castejon AM, Alfieri AB, Cubeddu LX: Endothelial nitric oxide synthase polymorphism, nitric oxide production, salt sensitivity and cardiovascular risk factors in Hispanics. $J$ Hum Hypertens 2005, 19(3):233-240.

50. Chrysohoou C, Panagiotakos DB, Pitsavos C, Antoniades C, Skoumas J, Brown M, Stefanadis C: Evidence for association between endothelial nitric oxide synthase gene polymorphism (G894T) and inflammatory markers: the ATTICA study. Am Heart J 2004, 148(4):733-738.

51. Senti M, Tomas M, Elosual R, Sala J, Masia R, Marrugat J: The paraoxonase1 codon 192 polymorphism is associated with fasting total cholesterol and LDL-cholesterol concentrations only in postmenopausal women. The REGICOR study. Clin Chem Lab Med 2002, 40(7):677-683.

52. Perez-Herrera N, May-Pech C, Hernandez-Ochoa I, Castro-Mane J, RojasGarcia E, Borja-Aburto VH, Castillo-Burguete T, Quintanilla-Vega B: PON1Q192R polymorphism is associated with lipid profile in Mexican men with Mayan ascendancy. Exp Mol Pathol 2008, 85(2):129-134.

53. Ranade K, Kirchgessner TG, lakoubova OA, Devlin JJ, DelMonte T, Vishnupad P, Hui L, Tsuchihashi Z, Sacks FM, Sabatine MS, Braunwald E, White TJ, Shaw PM, Dracopoli NC: Evaluation of the paraoxonases as candidate genes for stroke: Gln192Arg polymorphism in the paraoxonase 1 gene is associated with increased risk of stroke. Stroke 2005, 36(11):2346-2350

54. Lahiry P, Ban MR, Pollex RL, Feldman RD, Sawyez CG, Huff MW, Young TK, Bjerregaard P, Hegele RA: Common variants APOC3, APOA5, APOE and PON1 are associated with variation in plasma lipoprotein traits in Greenlanders. Int J Circumpolar Health 2007, 66(5):390-400.

55. Gamboa R, Zamora J, Rodriguez-Perez JM, Fragoso JM, Cardoso G, Posadas-Romero C, Vargas-Alarcon G: Distribution of paraoxonase PON1 gene polymorphisms in Mexican populations. Its role in the lipid profile. Exp Mol Pathol 2006, 80(1):85-90.

56. Blatter Garin MC, Moren X, James RW: Paraoxonase-1 and serum concentrations of HDL-cholesterol and apoA-I. J Lipid Res 2006, 47(3):515-520.

57. Srinivasan SR, Li S, Chen W, Tang R, Bond MG, Boerwinkle E, Berenson GS Q192R polymorphism of the paraoxanase 1 gene and its association with serum lipoprotein variables and carotid artery intima-media thickness in young adults from a biracial community. The Bogalusa Heart Study. Atherosclerosis 2004, 177(1):167-174.

58. Senti M, Tomas M, Marrugat J, Elosua R: Paraoxonase1-192 polymorphism modulates the nonfatal myocardial infarction risk associated with decreased HDLs. Arterioscler Thromb Vasc Biol 2001, 21(3):415-420.

59. Turban S, Fuentes F, Ferlic L, Brugada R, Gotto AM, Ballantyne CM, Marian AJ: A prospective study of paraoxonase gene Q/R192 polymorphism and severity, progression and regression of coronary atherosclerosis, plasma lipid levels, clinical events and response to fluvastatin. Atherosclerosis 2001, 154(3):633-640.

60. Manresa JM, Zamora A, Tomás M, Sentí M, Fitó M, Covas MI, Alcántara M, Latorre G, Escurriol V, Domingues S, Marrugat J: Relationship of classical and non-classical risk factors with genetic variants relevant to coronary heart disease. Eur J Cardiovasc Prev Rehabil 2006, 13(5):738-744.

61. Manresa JM, Tomas M, Ribes E, Pi-Figueras M, Aguilera A, Senti M, Marrugat J: Paraoxonase 1 gene 192 polymorphism, physical activity and lipoprotein in women. Med Clin (Barc) 2004, 122(4):126-129.

62. Mikkelsson J, Perola M, Wartiovaara U, Peltonen L, Palotie A, Penttila A, Karhunen PJ: Plasminogen activator inhibitor-1 (PAI-1) 4G/5G polymorphism, coronary thrombosis, and myocardial infarction in middle-aged Finnish men who died suddenly. Thromb Haemost 2000, 84(1):78-82

63. Weiss EJ, Bray PF, Tayback M, Schulman SP, Kickler TS, Becker LC, Weiss JL, Gerstenblith G, Goldschmidt-Clermont PJ: A polymorphism of a platelet glycoprotein receptor as an inherited risk factor for coronary thrombosis. N Engl J Med 1996, 334(17):1090-1094.

64. Carter AM, Catto AJ, Bamford JM, Grant PJ: Platelet GP IIla PIA and GP Ib variable number tandem repeat polymorphisms and markers of platelet activation in acute stroke. Arterioscler Thromb Vasc Biol 1998 18(7):1124-1131.
65. Slowik A, Dziedzic T, Turaj W, Pera J, Glodzik-Sobanska L, Szermer P, Malecki MT, Figlewicz DA, Szczudlik A: A2 alelle of Gpllla gene is a risk factor for stroke caused by large-vessel disease in males. Stroke 2004, 35(7):1589-1593.

66. Weiss LA, Abney M, Parry R, Scanu AM, Cook EH Jr, Ober C: Variation in ITGB3 has sex-specific associations with plasma lipoprotein(a) and whole blood serotonin levels in a population-based sample. Hum Genet 2005, 117(1):81-87.

67. Deo RC, Reich D, Tandon A, Akylbekova E, Patterson N, Waliszewska A, Kathiresan S, Sarpong D, Taylor HA Jr, Wilson JG: Genetic differences between the determinants of lipid profile phenotypes in African and European Americans: the Jackson Heart Study. PLoS Genet 2009, 5(1):e1000342.

68. Ford ES, Li C, Pearson WS, Zhao G, Mokdad AH: Trends in hypercholesterolemia, treatment and control among United States adults. Int J Cardio/ 2008, 140(2):226-235.

69. Li M, Ong KL, Tse HF, Cheung BM: Utilization of lipid lowering medications among adults in the United States 1999-2006. Atherosclerosis 2010, 208(2):456-60

70. Reiner-Benaim A: FDR control by the $\mathrm{BH}$ procedure for two-sided correlated tests with implications to gene expression data analysis. Biom J 2007, 49(1):107-126.

71. Risch N, Burchard E, Ziv E, Tang H: Categorization of humans in biomedical research: genes, race and disease. Genome Biol 2002, 3(7):comment2007.

72. Tseng M, Williams RC, Maurer KR, Schanfield MS, Knowler WC, Everhart JE: Genetic admixture and gallbladder disease in Mexican Americans. Am J Phys Anthropol 1998, 106(3):361-371.

73. McKeigue PM, Carpenter JR, Parra EJ, Shriver MD: Estimation of admixture and detection of linkage in admixed populations by a Bayesian approach: application to African-American populations. Ann Hum Genet 2000, 64(Pt 2):171-186.

74. Salari K, Choudhry S, Tang H, Naqvi M, Lind D, Avila PC, Coyle NE, Ung N, Nazario S, Casal J, Torres-Palacios A, Clark S, Phong A, Gomez I, Matallana H, Pérez-Stable EJ, Shriver MD, Kwok PY, Sheppard D, Rodriguez-Cintron W, Risch NJ, Burchard EG, Ziv E: Genetic admixture and asthma-related phenotypes in Mexican American and Puerto Rican asthmatics. Genet Epidemiol 2005, 29(1):76-86.

75. Shriver MD, Kennedy GC, Parra EJ, Lawson HA, Sonpar V, Huang J, Akey JM, Jones KW: The genomic distribution of population substructure in four populations using 8,525 autosomal SNPs. Hum Genomics 2004, 1(4):274-286.

76. Rodrigues AC, Rebecchi IM, Bertolami MC, Faludi AA, Hirata MH, Hirata RD: High baseline serum total and LDL cholesterol levels are associated with MDR1 haplotypes in Brazilian hypercholesterolemic individuals of European descent. Braz J Med Biol Res 2005, 38(9):1389-1397.

77. Hines LM, Hunter DJ, Stampfer MJ, Spiegelman D, Chu NF, Rifai N, Hankinson SE, Rimm EB: Alcohol consumption and high-density lipoprotein levels: the effect of ADH1C genotype, gender and menopausal status. Atherosclerosis 2005, 182(2):293-300.

78. laccarino G, Trimarco V, Lanni F, Cipolletta E, Izzo R, Arcucci O, De Luca N, Di Renzo G: beta-Blockade and increased dyslipidemia in patients bearing Glu27 variant of beta2 adrenergic receptor gene. Pharmacogenomics J 2005, 5(5):292-297.

79. Hallman DM, Srinivasan SR, Chen W, Boerwinkle E, Berenson GS: The beta(2)-adrenergic receptor Arg16-gly polymorphism and interactions involving beta(2)- and beta(3)-adrenergic receptor polymorphisms are associated with variations in longitudinal serum lipid profiles: the Bogalusa Heart Study. Metabolism 2004, 53(9):1184-1191.

80. Iwamoto N, Ogawa Y, Kajihara S, Hisatomi A, Yasutake T, Yoshimura T, Mizuta T, Hara T, Ozaki I, Yamamoto K: Gln27Glu beta2-adrenergic receptor variant is associated with hypertriglyceridemia and the development of fatty liver. Clin Chim Acta 2001, 314(1-2):85-91.

81. Ukkola O, Perusse L, Weisnagel SJ, Bergeron J, Despres JP, Rao DC, Bouchard C: Interactions among the glucocorticoid receptor, lipoprotein lipase, and adrenergic receptor genes and plasma insulin and lipid levels in the Quebec Family Study. Metabolism 2001, 50(2):246-252.

82. Dunajska K, Lwow F, Milewicz A, Jedrzejuk D, Laczmanski L, Belowska-Bien K, Urban J, Szuba A: beta(3)-adrenergic receptor polymorphism and metabolic syndrome in postmenopausal women. Gynecol Endocrinol 2008, 24(3):133-138. 
83. Porto PI, Garcia SI, Dieuzeide G, Gonzalez C, Landa MS, Pirola CJ: Clinical features of the metabolic syndrome in adolescents: minor role of the Trp64Arg beta3-adrenergic receptor gene variant. Pediatr Res 2004 55(5):836-841.

84. Okumura K, Matsui H, Ogawa Y, Takahashi R, Matsubara K, Imai H, Imamura A, Mizuno T, Tsuzuki M, Kitamura Y: The polymorphism of the beta3-adrenergic receptor gene is associated with reduced lowdensity lipoprotein particle size. Metabolism 2003, 52(3):356-361.

85. Manraj M, Francke S, Hebe A, Ramjuttun US, Froguel P: Genetic and environmental nature of the insulin resistance syndrome in IndoMauritian subjects with premature coronary heart disease: contribution of beta3-adrenoreceptor gene polymorphism and beta blockers on triglyceride and HDL concentrations. Diabetologia 2001, 44(1):115-122.

86. Zuntar I, Antoljak N, Vrkic N, Topic E, Kujundzic N, Demarin V, Vukovic V: Association of methylenetetrahydrofolate (MTHFR) and apolipoprotein $\mathrm{E}$ (apo E) genotypes with homocysteine, vitamin and lipid levels in carotid stenosis. Coll Antropol 2006, 30(4):871-878.

87. Loktionov A, Vorster H, O'Neill IK, Nell T, Bingham SA, Runswick SA, Cummings $\mathrm{JH}$ : Apolipoprotein $\mathrm{E}$ and methylenetetrahydrofolate reductase genetic polymorphisms in relation to other risk factors for cardiovascular disease in UK Caucasians and Black South Africans. Atherosclerosis 1999, 145(1):125-135.

88. Sawada T, Kishimoto T, Osaki Y, Okamoto M, Tahara A, Kaetu A, Kurosawa Y, Kotani K: Relation of the Glu298Asp polymorphism of the nitric oxide synthase gene to hypertension and serum cholesterol in Japanese workers. Prev Med 2008, 47(2):167-171.

89. Mackness B, Mackness MI, Arrol S, Turkie W, Durrington PN: Effect of the human serum paraoxonase 55 and 192 genetic polymorphisms on the protection by high density lipoprotein against low density lipoprotein oxidative modification. FEBS Lett 1998, 423(1):57-60.

90. Chambers JE: PON1 multitasks to protect health. Proc Natl Acad Sci USA 2008, 105(35):12639-12640

91. Fanella S, Harris SB, Young TK, Hanley AJ, Zinman B, Connelly PW, Hegele RA: Association between PON1 L/M55 polymorphism and plasma lipoproteins in two Canadian aboriginal populations. Clin Chem Lab Med 2000, 38(5):413-420.

92. Dedoussis GV, Theodoraki EV, Manios Y, Yiannakouris N, Panagiotakos D, Papoutsakis C, Skenderi K, Zampelas A: The Pro12Ala polymorphism in PPARgamma2 gene affects lipid parameters in Greek primary school children: A case of gene-to-gender interaction. Am J Med Sci 2007, 333(1):10-15

93. Maeda A, Gohda T, Funabiki K, Horikoshi S, Tomino Y: Peroxisome proliferator-activated receptor gamma gene polymorphism is associated with serum triglyceride levels and body mass index in Japanese type 2 diabetic patients. J Clin Lab Anal 2004, 18(6):317-321.

94. Tai ES, Corella D, Deurenberg-Yap M, Adiconis X, Chew SK, Tan CE, Ordovas JM: Differential effects of the C1431T and Pro12Ala PPARgamma gene variants on plasma lipids and diabetes risk in an Asian population. $J$ Lipid Res 2004, 45(4):674-685.

95. Chen S, Tsybouleva N, Ballantyne CM, Gotto AM Jr, Marian AJ: Effects of PPARalpha, gamma and delta haplotypes on plasma levels of lipids, severity and progression of coronary atherosclerosis and response to statin therapy in the lipoprotein coronary atherosclerosis study. Pharmacogenetics 2004, 14(1):61-71.

96. Eriksson J, Lindi V, Uusitupa M, Forsen T, Laakso M, Osmond C, Barker D: The effects of the Pro12Ala polymorphism of the PPARgamma-2 gene on lipid metabolism interact with body size at birth. Clin Genet 2003, 64(4):366-370.

97. Gonzalez Sanchez JL, Serrano Rios M, Fernandez Perez C, Laakso M, Martinez Larrad MT: Effect of the Pro12Ala polymorphism of the peroxisome proliferator-activated receptor gamma-2 gene on adiposity, insulin sensitivity and lipid profile in the Spanish population. Eur J Endocrino/ 2002, 147(4):495-501.

98. Swarbrick MM, Chapman CM, McQuillan BM, Hung J, Thompson PL, Beilby JP: A Pro12Ala polymorphism in the human peroxisome proliferatoractivated receptor-gamma 2 is associated with combined hyperlipidaemia in obesity. Eur J Endocrinol 2001, 144(3):277-282.

99. Kitamura Y, Okumura K, Imamura A, Mizuno T, Tsuzuki M, Numaguchi Y, Matsui $H$, Murohara T: Association of plasminogen activator inhibitor-1 4G/5G gene polymorphism with variations in the LDL particle size in healthy Japanese men. Clin Chim Acta 2004, 347(1-2):209-216.
100. Ruiz-Quezada S, Vazquez-Del Mercado M, Parra-Rojas I, Rangel-Villalobos H, Best-Aguilera C, Sanchez-Orozco LV, Munoz-Valle JF: Genotype and allele frequency of PAI-1 promoter polymorphism in healthy subjects from the west of Mexico. Association with biochemical and hematological parameters. Ann Genet 2004, 47(2):155-162.

101. Chen CH, Eng HL, Chang CJ, Tsai TT, Lai ML, Chen HY, Liu CJ, Lin TM: 4G/ $5 \mathrm{G}$ promoter polymorphism of plasminogen activator inhibitor-1, lipid profiles, and ischemic stroke. J Lab Clin Med 2003, 142(2):100-105.

102. Lopes C, Dina C, Durand E, Froguel P: PAI-1 polymorphisms modulate phenotypes associated with the metabolic syndrome in obese and diabetic Caucasian population. Diabetologia 2003, 46(9):1284-1290.

103. Parra-Rojas I, Ruiz-Madrigal B, Martinez-Lopez E, Panduro A: Influence of the -308 TNF-alpha and -174 IL-6 polymorphisms on lipid profile in Mexican subjects. Hereditas 2006, 143(2006):167-172.

104. Sookoian SC, Gonzalez C, Pirola CJ: Meta-analysis on the G-308A tumor necrosis factor alpha gene variant and phenotypes associated with the metabolic syndrome. Obes Res 2005, 13(12):2122-2131.

105. Davis CL, Wang X, Snieder H, Treiber FA: Genetic and environmental determinants of lipid profile in black and white youth: a study of four candidate genes. Ethn Dis 2005, 15(4):568-577.

\section{Pre-publication history}

The pre-publication history for this paper can be accessed here: http://www.biomedcentral.com/1471-2350/11/62/prepub

doi: 10.1186/1471-2350-11-62

Cite this article as: Chang et al., Genetic variants associated with fasting blood lipids in the U.S. population: Third National Health and Nutrition Examination Survey BMC Medical Genetics 2010, 11:62

\section{Submit your next manuscript to BioMed Central and take full advantage of:}

- Convenient online submission

- Thorough peer review

- No space constraints or color figure charges

- Immediate publication on acceptance

- Inclusion in PubMed, CAS, Scopus and Google Scholar

- Research which is freely available for redistribution

Submit your manuscript at www.biomedcentral.com/submit
C) Biomed Central 